\title{
Relative tectonic activity classification in the Kermanshah area, western Iran
}

\author{
M. Arian ${ }^{1}$ and Z. Aram ${ }^{2}$ \\ ${ }^{1}$ Department of Geology, Science and Research Branch, Islamic Azad university, Tehran, Iran \\ ${ }^{2}$ Department of Geology, Kermanshah Branch, Islamic Azad University, Kermanshah, Iran \\ Correspondence to: M. Arian (mehranarian@yahoo.com)
}

Received: 17 July 2014 - Published in Solid Earth Discuss.: 31 July 2014

Revised: 29 October 2014 - Accepted: 5 November 2014 - Published: 4 December 2014

\begin{abstract}
Due to the closing of the subduction zone and the collision of the Arabian and Eurasian plates, the High Zagros region has always been affected by a wide range of tectonic variations. In this research, the Gharasu River basin, which is located in the Kermanshah area, was selected as the study area, six geomorphic indices were calculated, and the results of each one were divided into three classes. Then, using the indices, relative tectonic activity was calculated, and their values were classified and analysed in four groups. Regions were identified as very high, high, moderate and low. In analysing the results and combining them with field observations and regional geology, the results were often associated and justified with field evidence. The highest value is located on the Dokeral anticline in the crush zone in Zagros. Most of the areas with high and moderate values of Index of Active Tectonics (IAT) are also located in the crush zone in Zagros. Crushing in this zone is because of the main fault mechanism of the Zagros region. The result in this paper confirms previous research in this region. At the eastern end of the study area, the value of Iat is high, which could be the result of the Sarab and Koh-e Sefid fault mechanisms.
\end{abstract}

\section{Introduction}

The study area is the Gharasu River basin, which is in the west of Iran. The river is located in the Zagros fold-thrust belt in the Kermanshah area (Fig. 1). The aim of this selection, as a study area, is to calculate different geomorphic indices to assess active tectonics of the area. The north-eastern area consists of a thin imbricate fan (thrust sequence) that causes the creation of fault breccias, shear zones, general crushing of formations with the development of a linear joint system, sudden cutting of layers and changing of their age and lithology in the nearby area. In this area, we can see a lot of tectonic windows (Karimi, 1999).

Since the rivers are sensitive to the recent tectonic activities and show a rapid reaction, the Gharasu River and other secondary rivers are selected for calculation of the indices. The geomorphologic studies of active tectonics in the late Pleistocene and Holocene are of utmost importance in evaluating earthquake hazard in tectonically active areas such as the Zagros (Keller and Pinter, 2002).

In this study, the Gharasu basin is divided into 89 subbasins and, if possible, each of the following indices is calculated: stream-gradient index $\left(S_{\mathrm{L}}\right)$, drainage basin asymmetry $\left(A_{\mathrm{f}}\right)$, hypsometric integral $\left(H_{\mathrm{i}}\right)$, valley floor width-valley height ratio $\left(V_{\mathrm{f}}\right)$, drainage basin shape $\left(B_{\mathrm{s}}\right)$, and mountainfront sinuosity $(J)$. We use geomorphic indices of active tectonics, known to be useful in active tectonic studies (Bull and McFaden, 1977; Azor et al., 2002; Molin et al., 2004; Silva et al., 2003; Keller and Pinter, 2002). This methodology has been tested previously as a valuable tool in different tectonically active areas, namely the south-western USA (Rockwell et al,1985), the Pacific coast of Costa Rica (Wells et al., 1988), the Mediterranean coast of Spain (Silva,1994), the south-western Sierra Nevada of Spain (El Hamdouni et al., 2008), and the Sarvestan area in the central Zagros of Iran (Dehbozorgi et al., 2010). These studies have proved useful. Furthermore, the results must be combined with the geology studies of the region and field observations in order to obtain the desired result. 


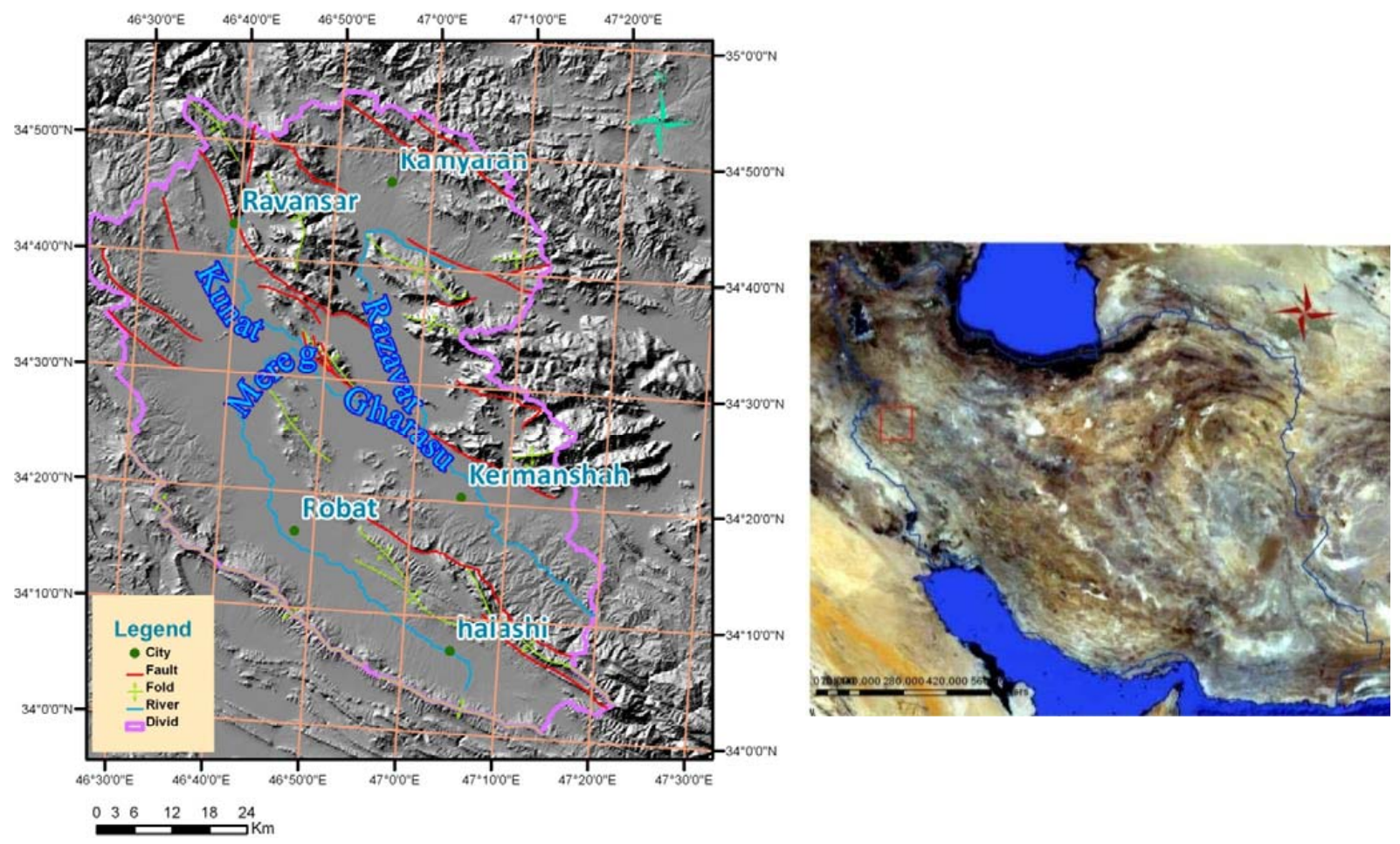

Figure 1. Location of the study area in Iran and the Zagros fold-thrust belt.

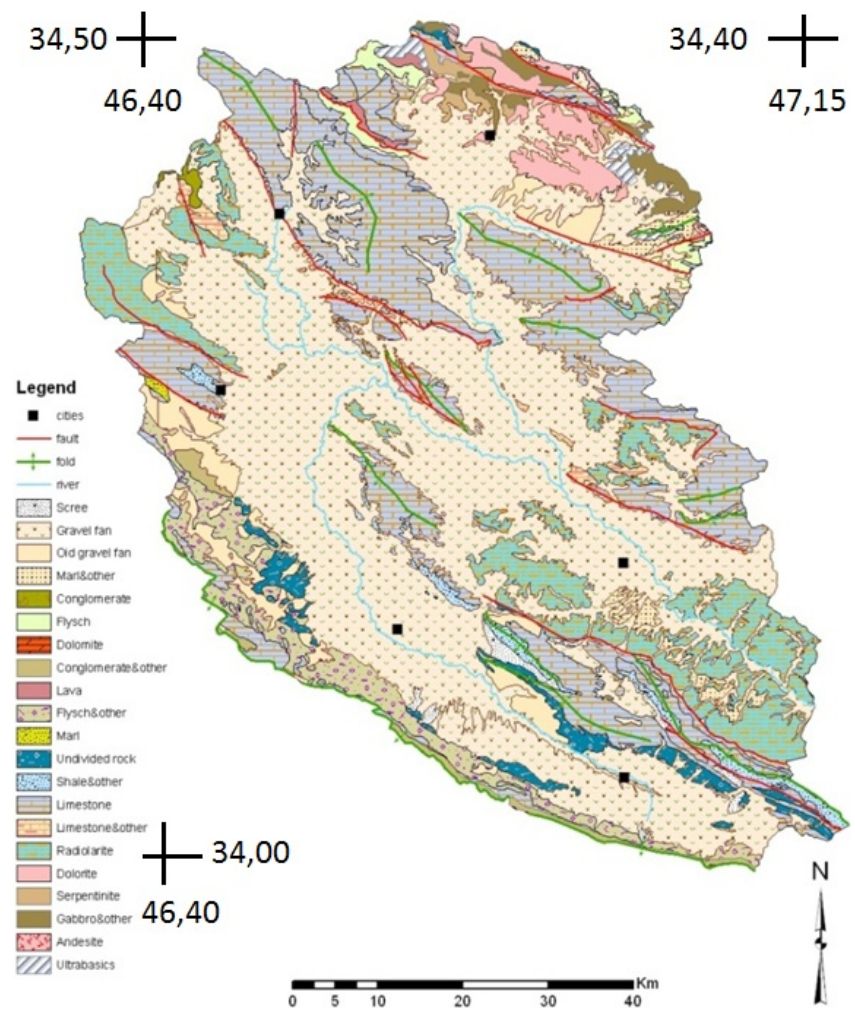

Figure 2. Geological map (1:250 000) of the study area.

\section{Regional and geological setting of the study area}

The area is located between latitudes 34 to $35^{\circ}$ north and longitudes 46.30 to $47.30^{\circ}$ west. The study area $\left(3470 \mathrm{~km}^{2}\right)$, which is located along the Zagros fold-thrust belt, with $1500 \mathrm{~m}$ in length, extends from the Taurus Mountains in south-eastern Turkey to the Minab fault to the east of the Strait of Hormuz (Mirzaei et al., 1998).

The study area according to the division of Braud (1979) contains some parts of autochthon Zagros, allochthon Zagros and thin imbricate fan (thrust sequence) (Fig. 2). Thrust dips in the area are less than $45^{\circ}$, but sometimes reach up to $70^{\circ}$ and form reverse faults (Karimi, 1999). The accomplished studies on area joints prove the largest direction of the main stress axis to be formed in the north, the north-east to the south, and the south-west (Nazari, 1998).

Since the area is influenced by Arabian plate pressure and since the thrust of central Iran has also occurred by the omission of the Neotethys Ocean on the Arabian plate, some of the faults are of a thrust kind and have a northwest-southeast trend, and the thrust is southwesterly.

\section{Materials and methods}

To study the indices, there is a formula to which we turn to describe each one of the indices; it is necessary to have some primary maps to calculate the indices, the most important of which are a digital elevation model (DEM), the 


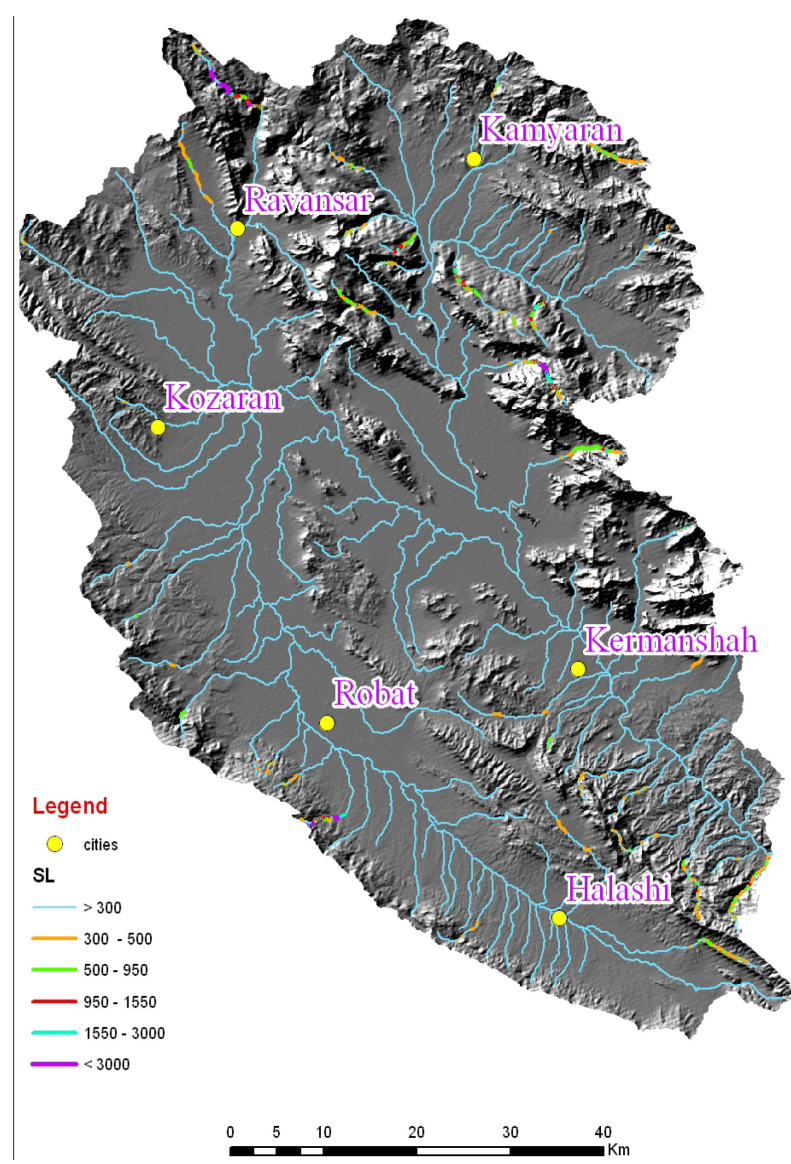

Figure 3. $S_{\mathrm{L}}$ index along the drainage network.

drainagenetwork and the sub-basin map of the Gharasu River basin that have been extracted from the DEM; DEM (The Shuttle Radar Topography Mission (SRTM)) extracted from a digitized topographic map $(1: 30000)$.

\subsection{The stream-gradient index $\left(S_{\mathrm{L}}\right)$}

The rivers flowing over rocks and soils of various strengths tend to reach equilibrium with specific longitudinal profiles and hydraulic geometrics (Hack, 1973; Bull, 2007). Hack $(1957,1973,1982)$ defined the index $\left(S_{\mathrm{L}}\right)$ to discuss influences of environmental variables on longitudinal stream profiles, and to test whether streams has reached an equilibrium. The calculation formula is in this manner:

$S_{\mathrm{L}}=(\Delta H / \Delta L) L$,

where $(\Delta H / \Delta L)$ is the local slope of the channel segment that is located between two contours, and $L$ is the channel length from the division to the midpoint of the channel reaches for which the index is calculated. To calculate the amount of $(\Delta H / \Delta L)$ and $L$, we need the contour and the drainage network map. The contours are gained from the DEM. In this study, the contour distances are set at $10 \mathrm{~m}$. This

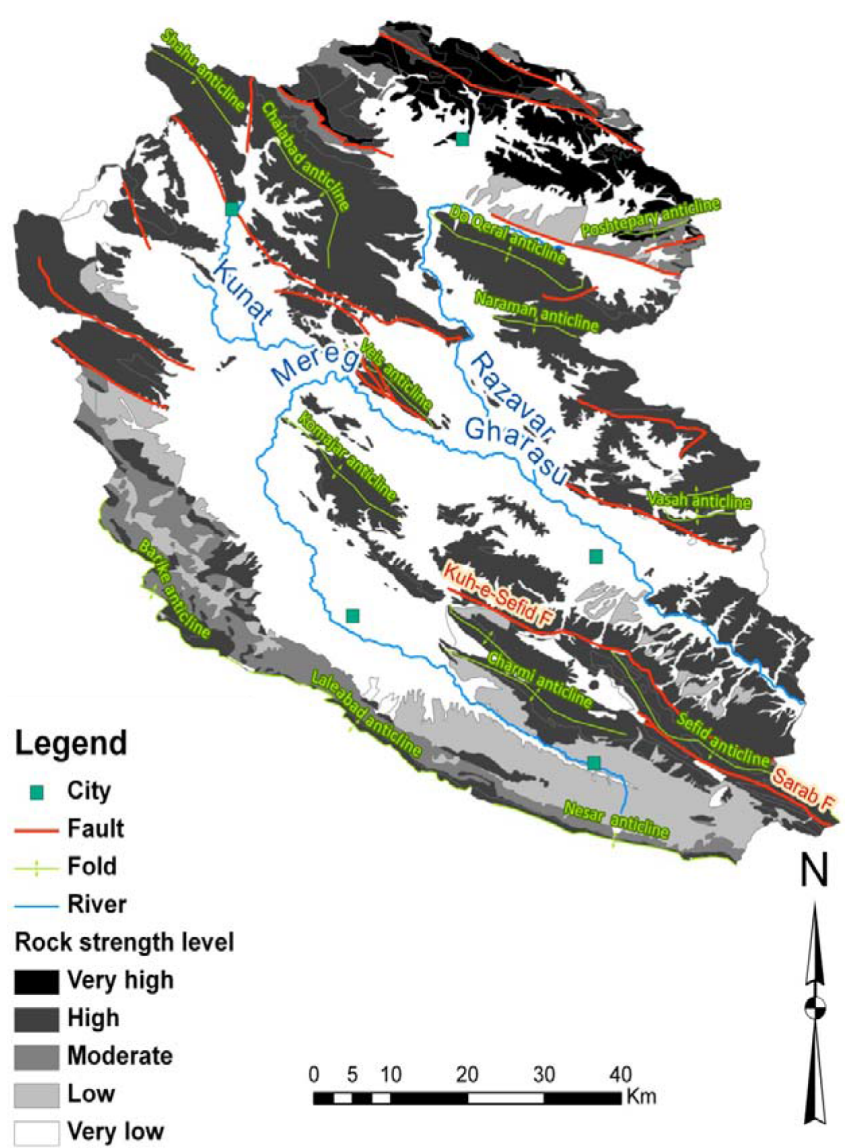

Figure 4. Distribution of rock strength levels in the area.

index is calculated along the master river for each sub-basin (Fig. 3) and, then, the $S_{\mathrm{L}}$ average is calculated for each one. The amount of $S_{\mathrm{L}}$ is not calculated for two sub-basins (49 and 57), because the values of contours which cut the master river are not adequate.

In Table 1, sub-basin 84 is brought up as an example. The $S_{\mathrm{L}}$ index can be used to evaluate relative tectonic activity (Keller and Pinter, 2002). An area of soft rocks with high $S_{\mathrm{L}}$ values can be indicative of active tectonics.

The $S_{\mathrm{L}}$ value is classified into three categories, which are class $1\left(S_{\mathrm{L}}>500\right)$, class $2\left(300<S_{\mathrm{L}}<500\right)$, and class 3 $\left(S_{\mathrm{L}}<300\right)$ (El Hamdouni et al., 2008). The minimum value of $S_{\mathrm{L}}$ is 1.33 , in sub-basin 2, and the maximum value is 7893.97, in sub-basin 88. After averaging each sub-basin, the maximum value is obtained for sub-basin 88 (16669), and two sub-basins, 49 and 57, do not possess any values (Table 1).

The mentioned index changes in stones with various resistances. The high resistances of rocks cause an increase in the values of the index. Anomaly in $S_{\mathrm{L}}$ can show the tectonic activity, so in order to analysis this index, the map of stone resistance is prepared (Fig. 4). In this map, the stones with very low resistance (young alluvial deposits), low resistance 
Table 1. Values of six geomorphic indices for 88 sub-basins of the Gharasu River basin $\left(S_{\mathrm{L}}\right.$ : stream length - gradient index; $A_{\mathrm{f}}$ : drainage basin asymmetry; $H_{\mathrm{i}}$ : hypsometric integral; $V_{\mathrm{f}}$ : ratio of the valley floor width to the valley height; $B_{\mathrm{S}}$ : index of the drainage basin shape; $J$ : index of mountain-front sinuosity).

\begin{tabular}{|c|c|c|c|c|c|c|c|}
\hline Sub-basin & Area & $S_{\mathrm{L}}$ & $A_{\mathrm{f}}$ & $B_{\mathrm{S}}$ & $J$ & $V_{\mathrm{f}}$ & $H_{\mathrm{i}}$ \\
\hline 1 & 135.41 & 147.38 & 33.17 & 2.36 & $\begin{array}{l}1.32 \\
1.08 \\
1.22 \\
1.20 \\
1.49\end{array}$ & $\begin{array}{l}0.00 \\
0.41\end{array}$ & 0.14 \\
\hline 2 & 12.97 & 62.00 & 69.70 & 2.83 & 1.32 & - & 0.25 \\
\hline 3 & 9.32 & 37.89 & 37.64 & 3.17 & 1.32 & - & 0.16 \\
\hline 4 & 7.98 & 74.57 & 47.61 & 3.45 & 1.32 & - & 0.32 \\
\hline 5 & 11.02 & 81.64 & 24.45 & 2.80 & 1.32 & - & 0.28 \\
\hline 6 & 76.51 & 262.87 & 91.81 & 2.52 & $\begin{array}{l}1.56 \\
1.20 \\
1.22\end{array}$ & - & 0.23 \\
\hline 7 & 20.20 & 170.60 & 71.66 & 4.09 & 1.32 & - & 0.38 \\
\hline 8 & 10.36 & 51.40 & 37.58 & 4.00 & - & - & 0.22 \\
\hline 9 & 19.54 & 374.88 & 44.25 & 2.20 & - & - & 0.36 \\
\hline 10 & 19.40 & 139.87 & 57.75 & 1.55 & - & - & 0.41 \\
\hline 11 & 12.51 & 77.73 & 26.44 & 2.62 & 1.56 & 2.58 & 0.43 \\
\hline 12 & 13.81 & 45.95 & 23.21 & 2.59 & 1.32 & - & 0.18 \\
\hline 13 & 33.56 & 261.56 & 53.07 & 2.09 & - & - & 0.44 \\
\hline 14 & 48.18 & 203.76 & 57.60 & 1.53 & - & - & 0.32 \\
\hline 15 & 66.80 & 137.40 & 35.70 & 2.51 & $\begin{array}{l}1.56 \\
1.15 \\
1.13\end{array}$ & $\begin{array}{l}2.63 \\
0.79 \\
1.44 \\
5.51 \\
9.34 \\
11.81\end{array}$ & 0.30 \\
\hline 16 & 56.55 & 87.24 & 19.18 & 1.80 & 1.32 & - & 0.27 \\
\hline 17 & 28.44 & 108.42 & 50.99 & 2.07 & 1.20 & - & 0.42 \\
\hline 18 & 10.29 & 67.44 & 56.10 & 1.93 & - & - & 0.44 \\
\hline 19 & 31.38 & 95.15 & 68.43 & 2.08 & 1.32 & 18.39 & 0.25 \\
\hline 20 & 22.68 & 177.54 & 66.01 & 2.27 & - & - & 0.33 \\
\hline 21 & 38.81 & 1362.04 & 39.78 & 1.63 & 1.32 & - & 0.36 \\
\hline 22 & 25.60 & 189.27 & 70.26 & 2.61 & - & - & 0.35 \\
\hline 23 & 16.40 & 231.04 & 85.06 & 2.18 & 1.32 & 9.41 & 0.32 \\
\hline 24 & 25.76 & 103.17 & 37.29 & 2.11 & - & - & 0.49 \\
\hline 25 & 11.33 & 39.58 & 46.26 & 1.68 & - & - & 0.47 \\
\hline 26 & 13.87 & 3 & 46.04 & 1.50 & - & - & 0.34 \\
\hline 27 & 14.46 & 50.84 & 51.13 & 2.04 & - & - & 0.45 \\
\hline 28 & 12.27 & 175.01 & 64.18 & 4.90 & 1.32 & $\begin{array}{l}1.53 \\
7.14\end{array}$ & 0.24 \\
\hline 29 & 21.62 & 137.13 & 54.33 & 2.53 & 1.32 & - & 0.16 \\
\hline 30 & 22.50 & 119.81 & 26.60 & 2.80 & - & - & 0.31 \\
\hline 31 & 10.81 & 161.70 & 57.75 & 6.57 & - & - & 0.34 \\
\hline 32 & 91.41 & 171.37 & 71.06 & 0.93 & $\begin{array}{l}1.49 \\
1.27 \\
1.13\end{array}$ & $\begin{array}{l}3.26 \\
4.82\end{array}$ & 0.39 \\
\hline 33 & 103.42 & 170.66 & 65.71 & 1.16 & - & - & 0.24 \\
\hline 34 & 157.15 & 106.04 & 39.47 & 1.95 & $\begin{array}{l}1.49 \\
1.28 \\
1.16 \\
1.20\end{array}$ & - & 0.23 \\
\hline 35 & 51.83 & 43.76 & 44.92 & 2.03 & 1.47 & - & 0.11 \\
\hline 36 & 15.31 & 30.80 & 62.75 & 2.56 & 1.47 & - & 0.10 \\
\hline 37 & 21.79 & 47.91 & 63.53 & 2.05 & - & - & 0.21 \\
\hline
\end{tabular}


Table 1. Continued.

\begin{tabular}{|c|c|c|c|c|c|c|c|}
\hline Sub-basin & Area & $S_{\mathrm{L}}$ & $A_{\mathrm{f}}$ & $B_{\mathrm{S}}$ & $J$ & $V_{\mathrm{f}}$ & $H_{\mathrm{i}}$ \\
\hline 38 & 47.53 & 254.04 & 60.69 & 2.20 & 1.47 & 1.44 & 0.17 \\
\hline 39 & 51.89 & 54.58 & 65.76 & 1.52 & - & - & 0.25 \\
\hline 40 & 20.21 & 20.90 & 29.02 & 2.08 & 1.51 & - & 0.23 \\
\hline 41 & 21.29 & 13.55 & 62.40 & 1.21 & 1.28 & - & 0.17 \\
\hline 42 & 15.00 & 89.76 & 47.07 & 0.98 & 1.47 & $\begin{array}{l}1.56 \\
0.18\end{array}$ & 0.17 \\
\hline 43 & 16.98 & 67.68 & 31.48 & 1.58 & 1.47 & - & 0.25 \\
\hline 44 & 100.39 & 137.96 & 25.03 & 2.26 & 1.51 & - & 0.17 \\
\hline 45 & 72.40 & 30.64 & 83.18 & 1.36 & - & - & 0.14 \\
\hline 46 & 35.74 & 116.66 & 47.17 & 3.12 & 1.51 & 1.05 & 0.29 \\
\hline 47 & 105.46 & 79.98 & 15.13 & 2.70 & $\begin{array}{l}1.49 \\
1.27\end{array}$ & - & 0.21 \\
\hline 48 & 21.91 & 102.71 & 66.03 & 2.98 & 1.27 & 4.14 & 0.21 \\
\hline 49 & 9.01 & - & 64.77 & 1.62 & - & - & 0.24 \\
\hline 50 & 155.18 & 154.77 & 44.84 & 1.14 & 1.47 & 0.40 & 0.27 \\
\hline 51 & 53.96 & 26.48 & 70.40 & 2.15 & $\begin{array}{l}1.28 \\
1.27\end{array}$ & - & 0.14 \\
\hline 52 & 42.75 & 9.65 & 46.92 & 1.23 & 1.27 & 12.41 & 0.11 \\
\hline 53 & 108.39 & 125.42 & 45.95 & 4.61 & 1.51 & - & 0.13 \\
\hline 54 & 38.29 & 85.19 & 48.13 & 6.11 & 1.43 & 3 & 0.22 \\
\hline 55 & 47.24 & 132.10 & 59.68 & 2.47 & 1.43 & - & 0.15 \\
\hline 56 & 194.59 & 558.88 & 58.04 & 0.70 & 2.00 & 0.08 & 0.18 \\
\hline 57 & 18.32 & - & 16.59 & 2.73 & 1.45 & - & 0.07 \\
\hline 58 & 146.18 & 112.99 & 69.69 & 3.81 & 1.51 & 0.38 & 0.28 \\
\hline 59 & 107.98 & 101.77 & 59.69 & 2.46 & $\begin{array}{l}1.45 \\
1.24 \\
1.30\end{array}$ & $\begin{array}{l}0.2 \\
0.2 \\
0.85\end{array}$ & 0.09 \\
\hline 60 & 38.55 & 1289.77 & 59.04 & 3.05 & 2.00 & $\begin{array}{l}0.38 \\
0.50\end{array}$ & 0.40 \\
\hline 61 & 24.70 & 94.38 & 61.94 & 1.69 & $\begin{array}{l}1.45 \\
1.30 \\
1.14\end{array}$ & 0.82 & 0.23 \\
\hline 62 & 24.43 & 39.60 & 52.66 & 1.31 & 2.00 & - & 0.15 \\
\hline 63 & 12.32 & 965.73 & 60.08 & 2.31 & 1.42 & - & 0.53 \\
\hline 64 & 18.38 & 9.82 & 50.90 & 1.70 & 1.45 & - & 0.27 \\
\hline 65 & 7.28 & 27.89 & 13.89 & 1.43 & 2.00 & - & 0.22 \\
\hline 66 & 118.71 & 76.09 & 66.94 & 1.55 & $\begin{array}{l}1.26 \\
1.25\end{array}$ & $\begin{array}{l}13.51 \\
9.66 \\
19.44\end{array}$ & 0.17 \\
\hline 67 & 152.17 & 85.69 & 61.84 & 0.74 & $\begin{array}{l}1.23 \\
1.42 \\
1.21\end{array}$ & $\begin{array}{l}4.89 \\
3.10 \\
3.32 \\
1.59\end{array}$ & 0.20 \\
\hline 68 & 53.01 & 403.87 & 64.82 & 2.78 & 1.14 & - & 0.33 \\
\hline 69 & 11.70 & 197.91 & 48.41 & 2.55 & 1.59 & 1.38 & 0.41 \\
\hline 70 & 28.94 & 742.88 & 33.88 & 5.36 & 1.42 & - & 0.49 \\
\hline 71 & 24.79 & 10.93 & 43.62 & 3.22 & 1.59 & - & 0.44 \\
\hline 72 & 98.37 & 137.32 & 57.94 & 1.77 & 1.25 & - & 0.36 \\
\hline 73 & 14.85 & 69.15 & 70.96 & 3.42 & - & - & 0.36 \\
\hline 74 & 20.40 & 129.56 & 62.15 & 2.74 & $\begin{array}{l}1.23 \\
1.68\end{array}$ & - & 0.31 \\
\hline 75 & 22.75 & 212.17 & 63.63 & 2.27 & 1.59 & 1.97 & 0.42 \\
\hline 76 & 12.66 & 98.62 & 58.45 & 2.45 & 1.68 & - & 0.31 \\
\hline 77 & 81.52 & 194.22 & 63.26 & 1.40 & 1.23 & - & 0.35 \\
\hline
\end{tabular}


Table 1. Continued.

\begin{tabular}{|c|c|c|c|c|c|c|c|}
\hline Sub-basin & Area & $S_{\mathrm{L}}$ & $A_{\mathrm{f}}$ & $B_{\mathrm{S}}$ & $J$ & $V_{\mathrm{f}}$ & $H_{\mathrm{i}}$ \\
\hline 78 & 58.74 & 96.92 & 77.88 & 1.45 & - & - & 0.32 \\
\hline 79 & 12.90 & 79.93 & 39.70 & 3.43 & 1.68 & - & 0.29 \\
\hline 80 & 16.45 & 35.93 & 18.43 & 1.92 & 1.68 & - & 0.24 \\
\hline 81 & 111.95 & 43.00 & 54.81 & 1.36 & - & - & 0.25 \\
\hline 82 & 49.20 & 224.02 & 69.93 & 1.79 & 1.59 & $\begin{array}{l}1.91 \\
0.62\end{array}$ & 0.42 \\
\hline 83 & 1048.63 & 60.79 & 49.80 & - & $\begin{array}{l}1.16 \\
1.16 \\
1.45 \\
1.14 \\
1.32 \\
1.32 \\
1.56 \\
1.20 \\
1.28 \\
1.34 \\
1.14 \\
1.23 \\
1.59 \\
1.51 \\
1.47 \\
2.00 \\
1.68 \\
1.42\end{array}$ & $\begin{array}{l}1.07 \\
1.35 \\
2.55 \\
12.01 \\
4.26 \\
1.79\end{array}$ & 0.13 \\
\hline 84 & 74.01 & 270.20 & 39.53 & 1.38 & 1.28 & - & 0.15 \\
\hline 85 & 160.89 & 301.99 & 30.90 & 1.32 & 2.04 & $\begin{array}{l}1.45 \\
1.74 \\
0.79\end{array}$ & 0.38 \\
\hline 86 & 42.34 & 91.71 & 53.13 & 2.96 & - & - & 0.21 \\
\hline 87 & 53.25 & 144.37 & 38.13 & 1.17 & - & - & 0.43 \\
\hline 88 & 177.04 & 1669.67 & 43.45 & 2.01 & 1.34 & $\begin{array}{l}0.28 \\
0.08 \\
0.85 \\
1.48\end{array}$ & 0.40 \\
\hline 89 & 167.97 & 73.37 & 61.94 & 1.05 & - & - & 0.26 \\
\hline
\end{tabular}

(older alluvial fan deposits), moderate resistance (shale, silt), high resistance (limestone, tuff, conglomerate, sandstone) and very high resistance (monzodiorite, monzogabbro, quartesite) are specified (Memarian, 2001).

By studying $S_{\mathrm{L}}$ values, it can be seen that in the northern part of the area, in spite of the existence of very highly resistant stone, the $S_{\mathrm{L}}$ value decreases (Fig. 3). The reason is the intense breakage of sediments and volcanic rocks, which thrust onto others by up-thrusting. Most of the sub-basins with high and moderate $S_{\mathrm{L}}$ values are located in the middle part of the study area, which has the same trending and strike as the main valleys and faults (north-west to south-east). Major exposed rocks above the area are crushed limestone. In the southern part of the area, the tectonic activity is often low, due to it going out from the active fault, low resistance of the rock, and young alluvial deposits. Some of the longi- tudinal river profiles and the measured $S_{\mathrm{L}}$ index are shown in Fig. 5.

\subsection{Asymmetry factor $\left(A_{f}\right)$}

This index is related to two-tectonic and no-tectonic factors. No-tectonic factors may relate to lithology and rock fabrics. It is a way of evaluating the existence of tectonic tilting at the scale of a drainage basin. The method may be applied over a relatively large area (Hare and Gardner, 1985; Keller and Pinter, 2002). The index is defined as follows:

$$
A_{\mathrm{f}}=\left(A_{\mathrm{r}} / A_{\mathrm{t}}\right) 100,
$$

where $A_{\mathrm{r}}$ is the right-side area of the master stream basin (looking downstream) and $A_{\mathrm{t}}$ is the total area of the basin that can be measured by Geographic Information System (GIS) software. To calculate this index in the area, $A_{\mathrm{t}}$ and $A_{\mathrm{r}}$ are 

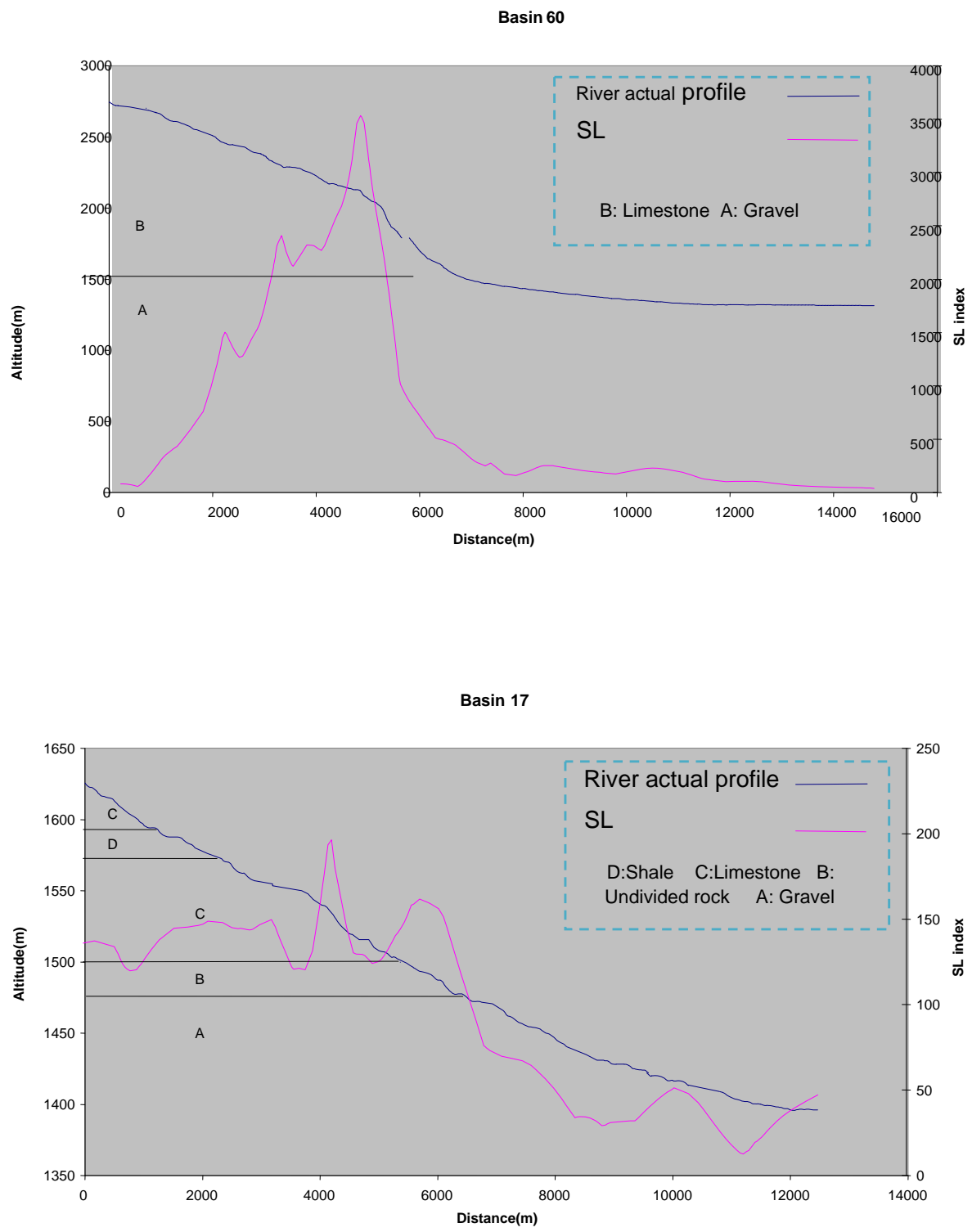

Figure 5. Longitudinal river profiles and measured $S_{\mathrm{L}}$ values for three sub-basins in the study area.

obtained using the sub-basins and the master river maps. $A_{\mathrm{f}}$ is close to 50 if there is no or little tilting perpendicular to the direction of the master stream. $A_{\mathrm{f}}$ is significantly greater or smaller than 50 under the effects of active tectonics or strong lithologic control. The values of this index are divided into three categories: $1\left(A_{\mathrm{f}}<35\right.$ or $\left.A_{\mathrm{f}}>63\right), 2\left(57<A_{\mathrm{f}}<65\right.$ or $\left.35<A_{\mathrm{f}}<43\right)$ and $3\left(43<A_{\mathrm{f}}<57\right)$ (El Hamdouni et al., 2008) (Table 1).

Among the obtained values, the minimum value belongs to sub-basin 65 , with $13.89 \%$, and the maximum value belongs to sub-basin 6, with $91.81 \%$. Regarding this index, we often see that all categories are scattered in the region, but class 3 is seen in the valleys and the sub-basins with low depth, and class 1 is spotted in the south-western margin of the study area.

\subsection{Hypsometric integral index $\left(H_{\mathbf{i}}\right)$}

The hypsometric integral $\left(H_{\mathrm{i}}\right)$ describes the relative distribution of elevation in a given area of a landscape, particularly a drainage basin (Strahler, 1952). The index is defined as the relative area below the hypsometric curve, and it is an important indicator of topographic maturity. $H_{\max }$ (maximum of hypsometric integral), $H_{\min }$ (minimum of hypsometric integral) and $H_{\text {ave }}$ (average of hypsometric integral) are calculated in the DEM here. This index is calculated for all sub-basins in the area, and the minimum value is 0.07 for sub-basin 56, and the maximum value is 0.53 for sub-basin 63 (Table 1). We can also obtain the value of the hypsometric integral from the area under the curve (Fig. 6). 


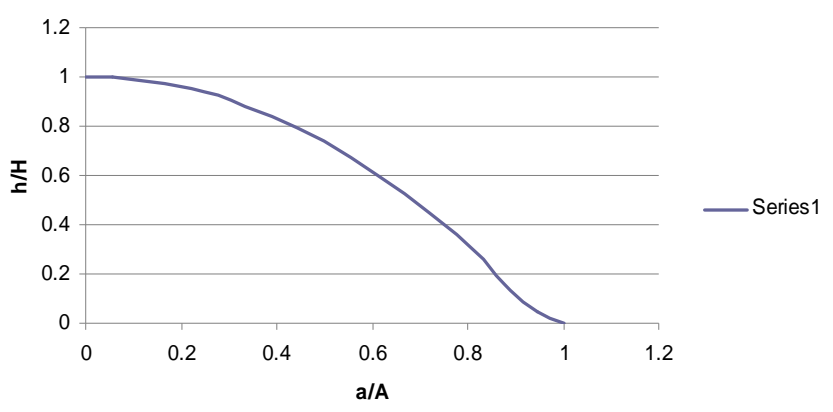

Sub-basin 22

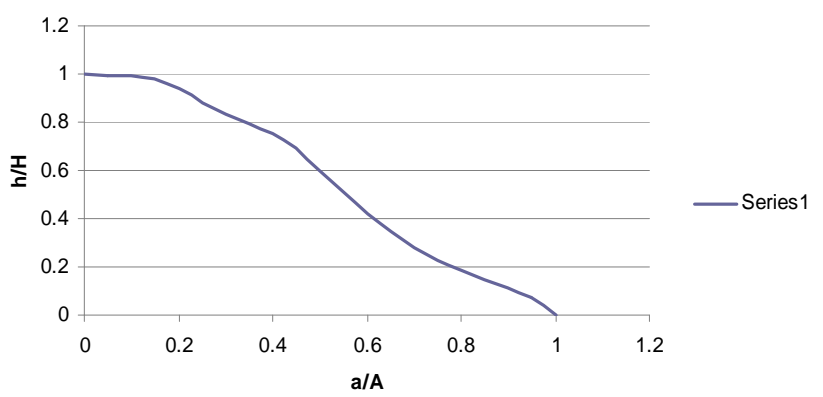

Sub-basin 82

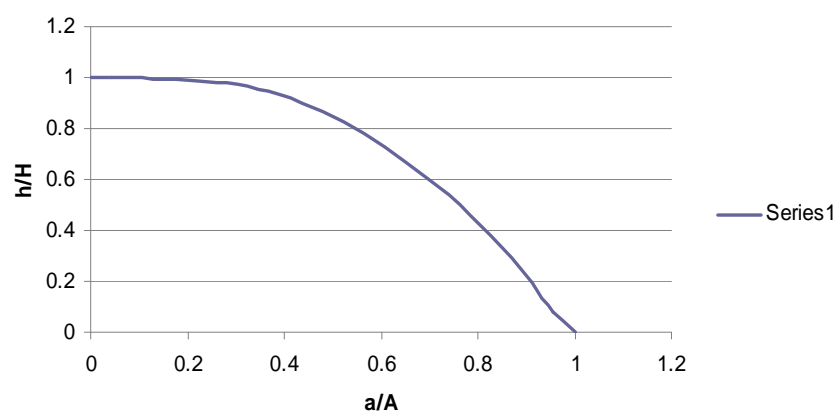

Sub-basin 89

Figure 6. Hypsometry curves of three sub-basins in the study area. $\mathbf{A}$ is the total surface of the basin. $\mathbf{a}$ is the surface area within the basin above a given line of elevation $\mathbf{h}$. $\mathbf{H}$ is the highest elevation of the basin.

The hypsometric integral reveals the maturity stages of topography that can, indirectly, be an indicator of active tectonics.

In general, high values of the hypsometric integral are convex, and these values are generally greater than 0.5 . Intermediate values tend to be more concave convex or straight, and generally have values between 0.4 and 0.5 . Finally, lower values $(<0.4)$ tend to have concave shapes (El Hamdouni et al., 2008).

The interesting point in the interpretation of the hypsometric index map is that the high to moderate values are approximately in the middle part of the study area, and they are almost similar to $S_{\mathrm{L}}$ anomalies too. The high and mod- erate values in this part have NE-SW trending (according to the trending of the area fault). Of course, there are other sub-basins with high and moderate values that after the mentioned area often show an increase in sub-basins which are located close to the Gharasu River in the south-eastern corner of the study area.

\subsection{Valley floor width-valley height ratio $\left(V_{f}\right)$}

Another index sensitive to tectonic uplift is the valley floor width to valley height ratio $\left(V_{\mathrm{f}}\right)$. This index can separate $v$ shaped valleys with small amounts from u-shaped valleys with greater amounts. The calculation formula is in this manner:

$V_{\mathrm{f}}=2 V_{\mathrm{f}, \mathrm{w}} /\left(A_{\mathrm{ld}}+A_{\mathrm{rd}}-2 A_{\mathrm{sc}}\right)$,

where $V_{\mathrm{f}, \mathrm{w}}$ is the width of the valley floor, and $A_{\mathrm{ld}}, A_{\mathrm{rd}}$ and $A_{\text {sc }}$ are the altitudes of the left and right divisions (looking downstream) and the stream channel, respectively (Bull, 2007). Bull and McFadden (1977) found significant differences in $V_{\mathrm{f}}$ between tectonically active and inactive mountain fronts. Also, they found significant differences in $V_{\mathrm{f}}$ between tectonically active and inactive mountain fronts (Fig. 7), because a valley floor is narrowed due to rapid stream downcutting.

Valleys upstream from the mountain front tend to be narrow (Ramirez-Herrera, 1998), and $V_{\mathrm{f}}$ is usually computed at a given distance upstream from the mountain front (Silva et al., 2003). We set a distance to $2 \mathrm{~km}$, and within the mountain range. The $V_{\mathrm{f}}$ of the main transverse valleys in the study area was calculated by a cross section that is drawn from the DEM and the topographic map (Fig. 8).

The $V_{\mathrm{f}, \mathrm{w}}$ value is obtained by measuring the length of a line which cuts the river and is limited to two sides of a contour through which the river crosses. Values of $A_{\text {ld }}$ (Altitude of the river-right valley divide), $A_{\mathrm{rd}}$ (Altitude of the river-left valley divide), and $A_{\mathrm{sc}}$ (Altitude of the stream channel) are measured using the drawn profile. Since finding that the place of $V_{\mathrm{f}}$ is independent of the sub-basins, it is possible that some of them have no $V_{\mathrm{f}}$ value and that some others have various $V_{\mathrm{f}}$ values (Table 1). $V_{\mathrm{f}}$ values are divided into three classes: $1\left(V_{\mathrm{f}}<0.3\right), 2\left(0.3<V_{\mathrm{f}}<1\right)$, and $3\left(V_{\mathrm{f}}>1\right)$ (El Hamdouni, 2008) (Fig. 9).

Some sub-basins, due to the lack of a suitable valley, have no value, and others have values from zero for sub-basin 1 to 19.44 for sub-basin 66. Most of the valleys are in class 3 and show U-shaped valleys, but the moderate to high values are often located in the northern part of the study area. The interesting point is that in the middle part of the area, the $V_{\mathrm{f}}$ index in the north-westerly-south-easterly direction in the same direction as other indices such as $S_{\mathrm{L}}$ and $H_{\mathrm{i}}$ shows moderate to high classes, which is in accordance with the main faults of the Zagros. 


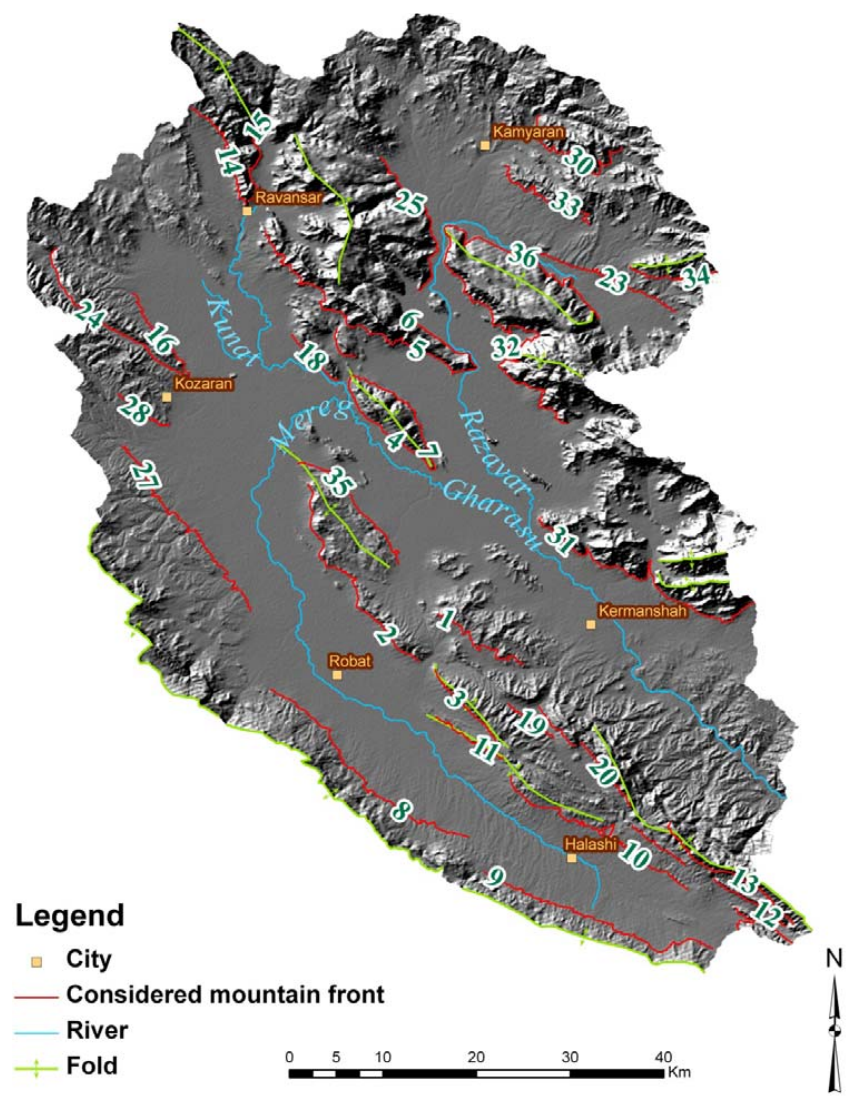

Figure 7. Thirty-six mountain fronts for the assessment of the $J$ index.

\subsection{Basin shape index $\left(B_{\mathrm{s}}\right)$}

Relatively young drainage basins in active tectonic areas tend to be more elongated than their normal shape on the topographic slope of a mountain. The elongated shape tends to evolve into a more circular shape (Bull and McFadden, 1977). The horizontal projection of the basin shape may be described by the basin shape index or elongation ratio, $B_{\mathrm{s}}$ (Cannon, 1976; Ramirez-Herrera, 1998). The calculation formula is $B_{\mathrm{s}}=B_{1} / B_{\mathrm{w}}$, where $B_{1}$ is the length of the basin measured from the headwater to the mountain, and $B_{\mathrm{w}}$ is the basin width at the widest point of the basin.

To calculate this index in the area, $B_{1}$ and $B_{\mathrm{w}}$ are obtained using the sub-basins and the master river maps; then, the values are divided into three classes: $1\left(B_{\mathrm{s}}>4\right), 2\left(3<B_{\mathrm{s}}<4\right)$, and $3\left(B_{\mathrm{S}}<3\right)$ (El Hamdouni et al., 2008) (Fig. 9; Table 1). The minimum value belongs to sub-basin 56 , with 0.7 , and the maximum value belongs to sub-basin 31 , with 6.37 . The other sub-basins have values between these two values.

$B_{\mathrm{S}}$ values show a few activities in most parts of the study area, but classes 2 and 3 are often scattered in the southwestern margin and the middle part of the study area.

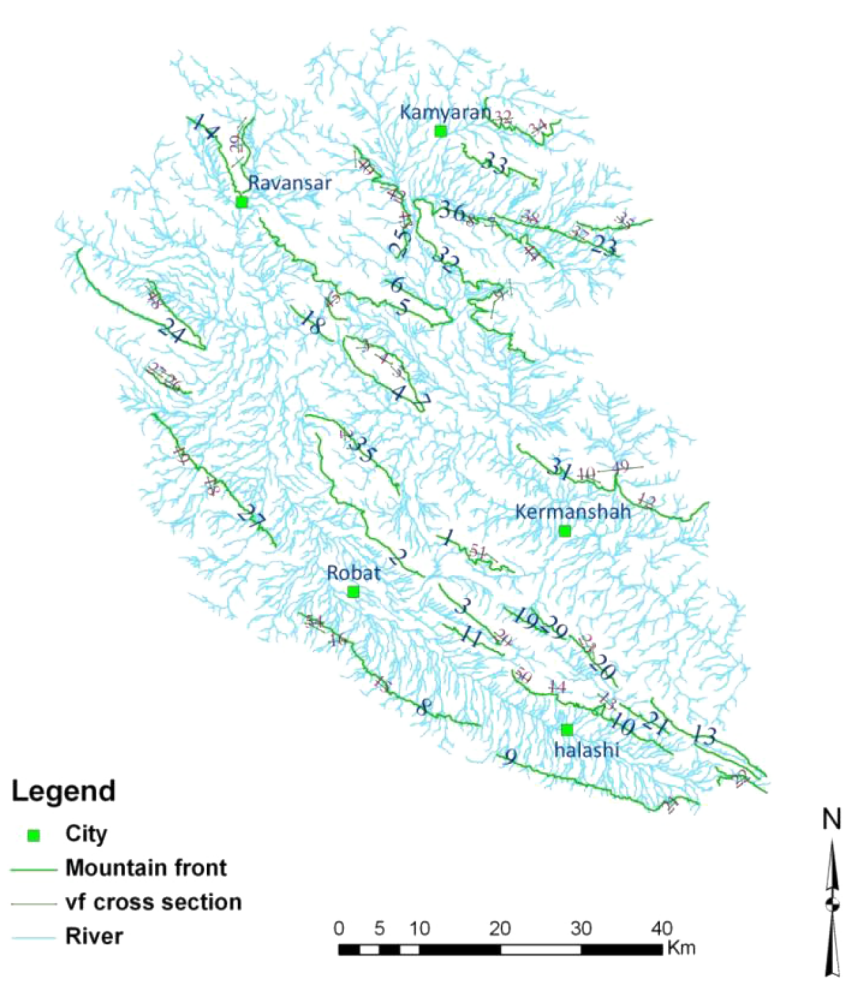

Figure 8. Location of the section for $V_{\mathrm{f}}$ calculation.

\subsection{Mountain-front sinuosity index $(J)$}

This index represents a balance between stream erosion processes tending to cut some parts of a mountain front and active vertical tectonics that tend to produce straight mountain fronts (Bull and McFadden, 1977; Keller, 1986). The index of mountain-front sinuosity (Bull and McFadden, 1977; Bull, 2007) is defined by

$J=L_{\mathrm{j}} / L_{\mathrm{S}}$,

where $L_{\mathrm{j}}$ is the planimetric length of the mountain along the mountain-piedmont junction, and $L_{\mathrm{S}}$ is the straight-line length of the front. The mountain fronts of the study area are drawn by fault and fold sites. $J$ is commonly less than 3 , and approaches 1 where steep mountains rise rapidly along a fault or fold (Bull, 2007). Therefore, this index can play an important role in tectonic activity. Considering the fact that mountain-front sites are independent of sub-basin places, chances are that some of them have various fronts and that the others have no mountain fronts (Table 1).

Values of $J$ are readily calculated from topographic maps or aerial photography for 36 mountain fronts (Fig. 7). $J$ values are divided into three classes: $1(J<1.1), 2(1.1<J<$ $1.5)$, and $3(J>1.5)$ (El Hamdouni, 2008).

In the study area, most of the obtained values are between 1.1 and 1.5 (class 2), and the parts which are in class 3 are often located in the northern part of the area. It should be mentioned that class 1 does not exist in the study area (Fig. 9). 

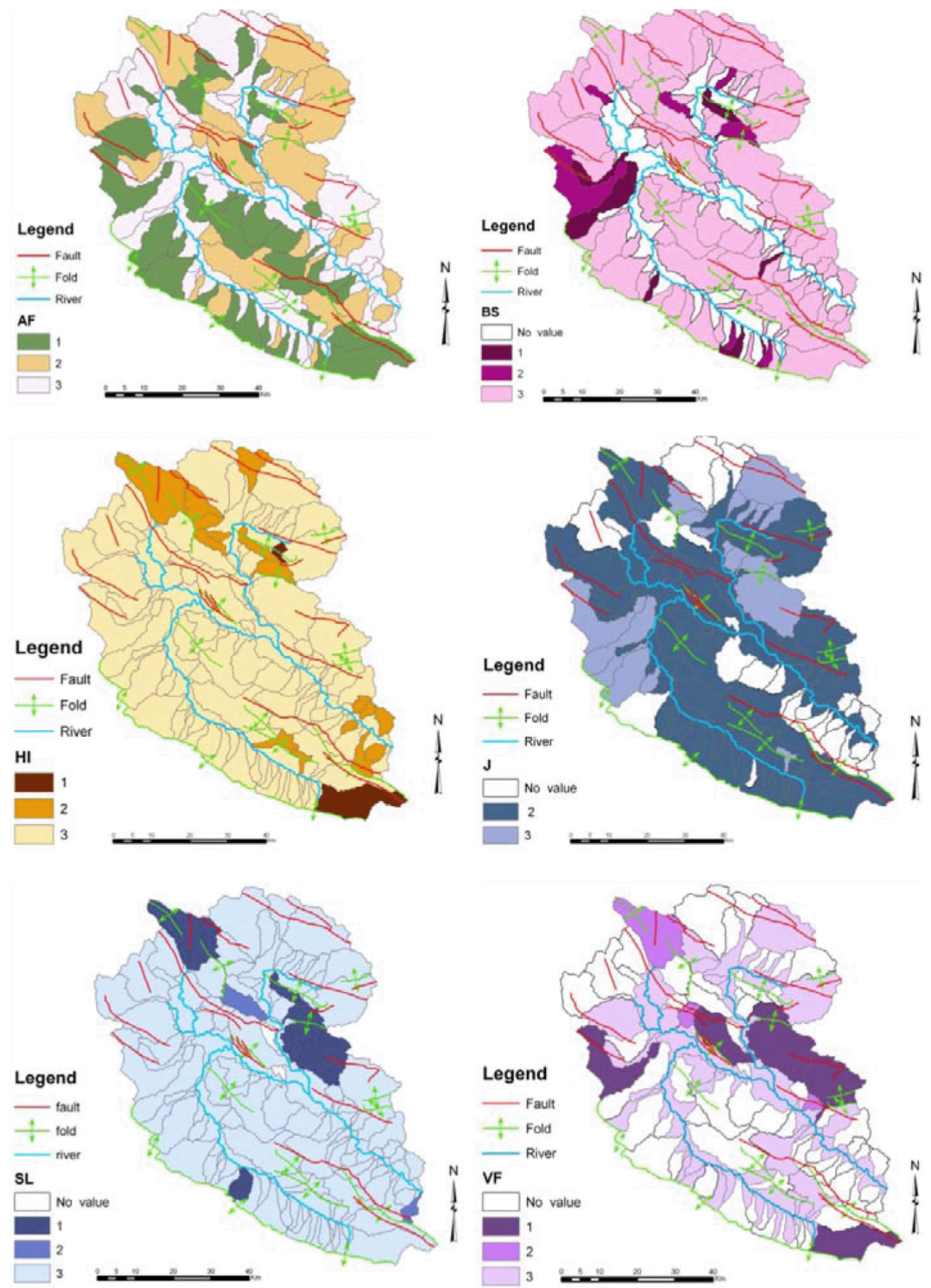

Figure 9. Distribution of six indices, $H_{\mathrm{i}}, V_{\mathrm{f}}, J, B_{\mathrm{S}}, A_{\mathrm{f}}$, and $S_{\mathrm{L}}$, and classification of them into three classes.

\section{Results and discussion}

The average of the six measured geomorphic indices $\left(V_{\mathrm{f}}, J\right.$, $B_{\mathrm{s}}, A_{\mathrm{f}}, H_{\mathrm{i}}$, and $S_{\mathrm{L}}$ ) was used to evaluate the distribution of relative tectonic activity. Each of the indices was divided into three classes. By averaging these six indices, we obtain one index that is a known relative active tectonic $\left(I_{\mathrm{at}}\right)(\mathrm{El} \mathrm{Ham}-$ douni et al., 2008). The values of the index were divided into four classes to define the degree of active tectonics: 1 - very high $\left(1<I_{\text {at }}<1.5\right), 2-$ high $\left(1.5<I_{\text {at }}<2\right), 3-$ moderate $\left(2<I_{\mathrm{at}}<2.5\right)$, and $4-$ low $\left(2.5<I_{\mathrm{at}}\right)$ (El Hamdouni et al., 2008)

The distribution of these four classes is shown in Fig. 10. In this map, the high and moderate values of Iat in the middle part of the area are obvious, and sub-basins 1, 2, and 6 (at the end of the south-western part of the area) have high to 


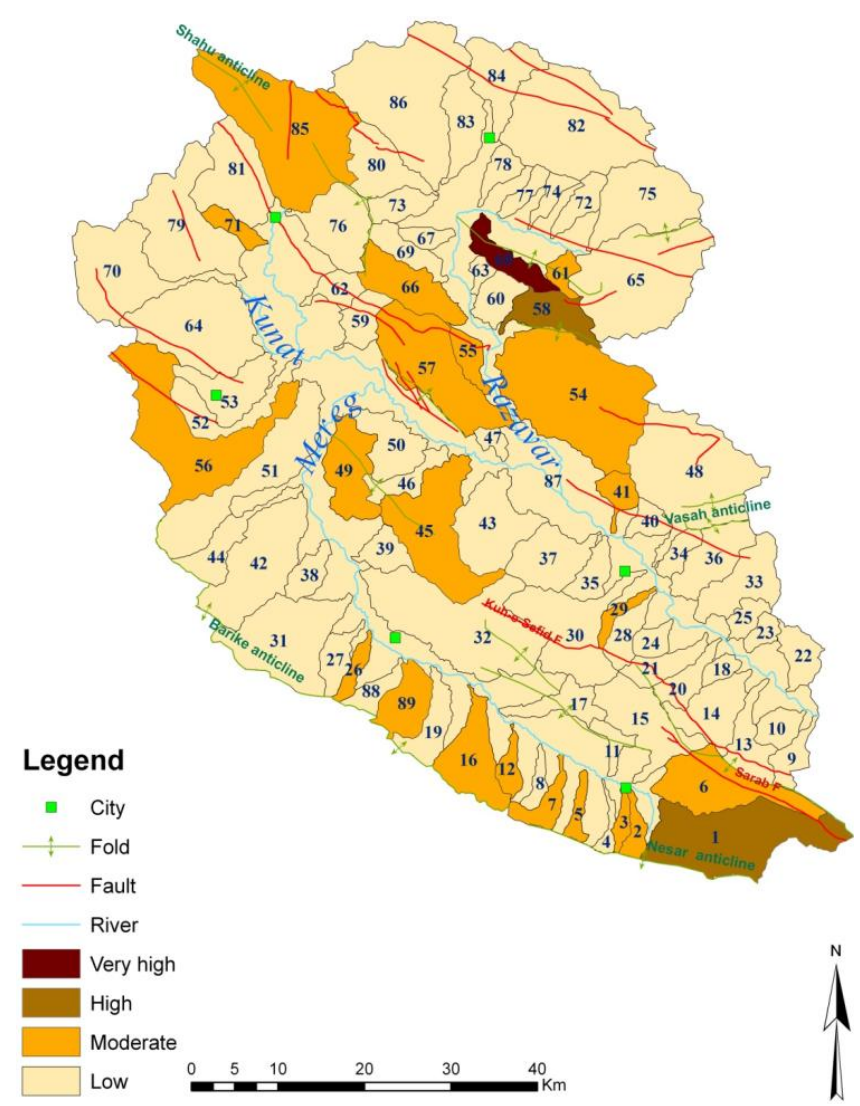

Figure 10. Distribution of $I_{\mathrm{at}}$ classes.

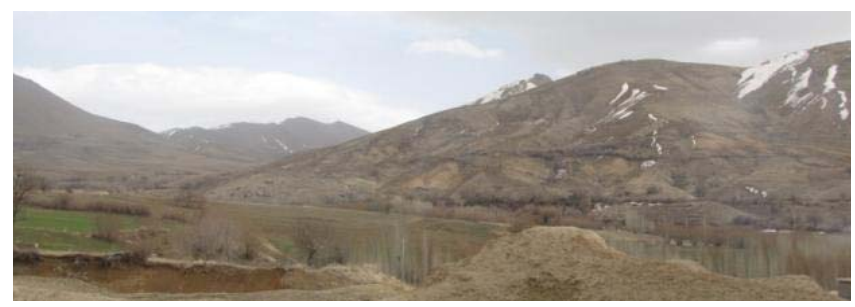

Figure 11. A view of faulting north of the study area, looking to the north-west.

moderate values of Iat too. Table 2 shows the result of the classification for each sub-basin. Also, based on Arian and Hashemi (2008), this area is a high seismic risk zone, with the following seismicity parameters: $a=3.79, b=0.50$, and $\beta=1.72$, and lambda for $M=4$ is 1.47 .

In the study area from the south to the north, we have three subdivisions: (1) autochthon Zagros; (2) radiolaritic overthrust nappes, Bisotun limestone and Ophiolite; and a (3) thin imbricate fan (thrust sequence) (Broud, 1979). In the northern parts of the area, complexities of flysch (CretaceousPaleocene) and Ophiolite assemblage (like disturbed basic layers) appear.

In the Neogene, basic magma intruded along the Morvaride fault (Fig. 11) and formed a broad gabbro-diorite mas-

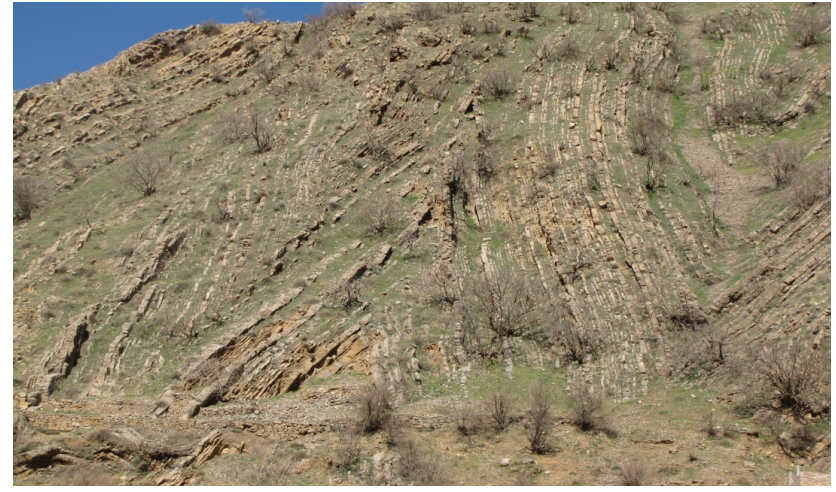

Figure 12. Intense folding and crushing in Biseton limestone located $60 \mathrm{~km}$ north-east of the village of Bencheleh, looking towards the north-east.

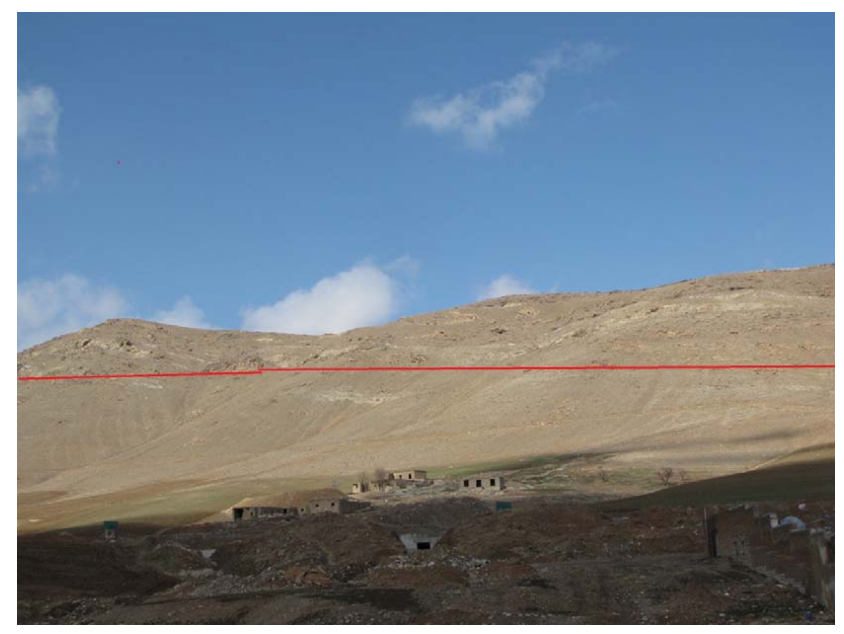

Figure 13. A view of the Koh-e Sefid fault located $6 \mathrm{~km}$ east of Halashi, looking north.

sive body in the northern Kamyaran. The function of tectonic phases results in the existence of regional metamorphisms such as green schist facies in flysch stones (CretaceousPaleocene). The traces of this metamorphism cause the appearance of serpentine in the area (Sadeghian and Delavar, 2007).

In the southern part of the area, thrust faults of a listric extensional kind are seen, striking from north-northwest to south-southeast (Karimi, 1999). It seems that the activity of these faults led to an increase in the relative tectonic activity of class 3. The limestone of Bisotun and the radiolarite of Kermanshah, which are extended in the centre of the study area, are separated from autochthon Zagros by the Koh-e Sefid fault. Bisotun limestone is a very thick and mainly stony unit which contains upper Triassic to upper Cretaceous age range (Braud, 1979). Bisotun limestone has intense folds (Fig. 12) and faults in the area which have caused the creation of important anticlines such as Dokral, Naraman, Chalabad, and Shahoo in their direction, and classes 1, 2, and 3 of the Iat 
Table 2. Classification of the $I_{\text {at }}$ (relative tectonic activity index) in the sub-basins of the Gharasu River basin $\left(S_{\mathrm{L}}\right.$ : stream length - gradient index; $A_{\mathrm{f}}$ : drainage basin asymmetry; $H_{\mathrm{i}}$ : hypsometric integral; $V_{\mathrm{f}}$ : ratio of the valley floor width to the valley height; $B_{\mathrm{s}}$ : index of drainage basin shape; $J$ : index of mountain-front sinuosity).

\begin{tabular}{|c|c|c|c|c|c|c|c|c|c|}
\hline Sub-basin & Area & $S_{\mathrm{L}}$ & $A_{\mathrm{f}}$ & $B_{\mathrm{S}}$ & $\mathrm{J}$ & $V_{\mathrm{f}}$ & $H_{\mathrm{i}}$ & $S / n$ & $I_{\text {at }}$ \\
\hline 1 & 135.41 & 3 & 1 & 3 & 2 & 1 & 1 & 1.83 & 2 \\
\hline 2 & 12.97 & 3 & 1 & 3 & 2 & - & 3 & 2.40 & 3 \\
\hline 3 & 9.32 & 3 & 2 & 2 & 2 & - & 3 & 2.40 & 3 \\
\hline 4 & 7.98 & 3 & 3 & 2 & 2 & - & 3 & 2.60 & 4 \\
\hline 5 & 11.02 & 3 & 1 & 3 & 2 & - & 3 & 2.40 & 3 \\
\hline 6 & 76.51 & 3 & 1 & 3 & 2 & - & 3 & 2.40 & 3 \\
\hline 7 & 20.20 & 3 & 1 & 1 & 2 & - & 3 & 2.00 & 3 \\
\hline 8 & 10.36 & 3 & 2 & 2 & - & - & 3 & 2.50 & 4 \\
\hline 9 & 19.54 & 2 & 3 & 3 & - & - & 3 & 2.75 & 4 \\
\hline 10 & 19.40 & 3 & 2 & 3 & - & - & 2 & 2.50 & 4 \\
\hline 11 & 12.51 & 3 & 1 & 3 & 3 & 3 & 2 & 2.50 & 4 \\
\hline 12 & 13.81 & 3 & 1 & 3 & 2 & - & 3 & 2.40 & 3 \\
\hline 13 & 33.56 & 3 & 3 & 3 & - & - & 2 & 2.75 & 4 \\
\hline 14 & 48.18 & 3 & 2 & 3 & - & - & 3 & 2.75 & 4 \\
\hline 15 & 66.80 & 3 & 2 & 3 & 2 & 3 & 3 & 2.67 & 4 \\
\hline 16 & 56.55 & 3 & 1 & 3 & 2 & - & 3 & 2.40 & 3 \\
\hline 17 & 28.44 & 3 & 3 & 3 & 2 & - & 2 & 2.60 & 4 \\
\hline 18 & 10.29 & 3 & 3 & 3 & - & - & 2 & 2.75 & 4 \\
\hline 19 & 31.38 & 3 & 1 & 3 & 2 & 3 & 3 & 2.50 & 4 \\
\hline 20 & 22.68 & 3 & 1 & 3 & - & - & 3 & 2.50 & 4 \\
\hline 21 & 38.81 & 1 & 2 & 3 & 2 & - & 3 & 2.50 & 4 \\
\hline 22 & 25.60 & 3 & 1 & 3 & - & - & 3 & 2.50 & 4 \\
\hline 23 & 16.40 & 3 & 1 & 3 & 2 & 3 & 3 & 2.75 & 4 \\
\hline 24 & 25.76 & 3 & 2 & 3 & - & - & 2 & 3.00 & 4 \\
\hline 25 & 11.33 & 3 & 3 & 3 & - & - & 2 & 2.75 & 4 \\
\hline 26 & 13.87 & 3 & 3 & 3 & - & - & 3 & 2.33 & 3 \\
\hline 27 & 14.46 & 3 & 3 & 3 & - & - & 2 & 2.80 & 4 \\
\hline 28 & 12.27 & 3 & 2 & 1 & 2 & 3 & 3 & 2.50 & 4 \\
\hline 29 & 21.62 & 3 & 3 & 3 & 2 & - & 3 & 2.25 & 3 \\
\hline 30 & 22.50 & 3 & 1 & 3 & - & - & 3 & 2.50 & 4 \\
\hline 31 & 10.81 & 3 & 2 & 1 & - & - & 3 & 2.50 & 4 \\
\hline 32 & 91.41 & 3 & 1 & 3 & 2 & 3 & 3 & 2.60 & 4 \\
\hline 33 & 103.42 & 3 & 1 & 3 & - & - & 3 & 2.80 & 4 \\
\hline 34 & 157.15 & 3 & 2 & 3 & 2 & - & 3 & 2.60 & 4 \\
\hline 35 & 51.83 & 3 & 3 & 3 & 2 & - & 3 & 2.75 & 4 \\
\hline 36 & 15.31 & 3 & 2 & 3 & 2 & - & 3 & 2.67 & 4 \\
\hline 37 & 21.79 & 3 & 2 & 3 & - & - & 3 & 2.50 & 4 \\
\hline 38 & 47.53 & 3 & 2 & 3 & 2 & 3 & 3 & 2.60 & 4 \\
\hline 39 & 51.89 & 3 & 1 & 3 & - & - & 3 & 2.60 & 4 \\
\hline 40 & 20.21 & 3 & 1 & 3 & 3 & - & 3 & 2.67 & 4 \\
\hline 41 & 21.29 & 3 & 2 & 3 & 2 & - & 3 & 2.40 & 3 \\
\hline 42 & 15.00 & 3 & 3 & 3 & 2 & 2 & 3 & 2.60 & 4 \\
\hline 43 & 16.98 & 3 & 1 & 3 & 2 & - & 3 & 2.50 & 4 \\
\hline 44 & 100.39 & 3 & 1 & 3 & 3 & - & 3 & 3.00 & 4 \\
\hline 45 & 72.40 & 3 & 1 & 3 & - & - & 3 & 2.40 & 3 \\
\hline 46 & 35.74 & 3 & 3 & 3 & 3 & 3 & 3 & 2.50 & 4 \\
\hline 47 & 105.46 & 3 & 1 & 3 & 2 & - & 3 & 2.67 & 4 \\
\hline 48 & 21.91 & 3 & 1 & 3 & 2 & 3 & 3 & 2.50 & 4 \\
\hline 49 & 9.01 & - & 2 & 3 & - & - & 3 & 2.40 & 3 \\
\hline 50 & 155.18 & 3 & 3 & 3 & 2 & 1 & 3 & 2.83 & 4 \\
\hline 51 & 53.96 & 3 & 1 & 3 & 2 & - & 3 & 2.60 & 4 \\
\hline 52 & 42.75 & 3 & 3 & 3 & 2 & 3 & 3 & 2.50 & 4 \\
\hline 53 & 108.39 & 3 & 3 & 1 & 3 & - & 3 & 2.60 & 4 \\
\hline
\end{tabular}


Table 2. Continued.

\begin{tabular}{llllllllll}
\hline Sub-basin & Area & $S_{\mathrm{L}}$ & $A_{\mathrm{f}}$ & $B_{\mathrm{S}}$ & $\mathrm{J}$ & $V_{\mathrm{f}}$ & $H_{\mathrm{i}}$ & $S / n$ & $I_{\mathrm{at}}$ \\
\hline 54 & 38.29 & 3 & 3 & 1 & 2 & 3 & 3 & 2.17 & 3 \\
55 & 47.24 & 3 & 2 & 3 & 2 & - & 3 & 2.25 & 3 \\
56 & 194.59 & 1 & 2 & 3 & 3 & 1 & 3 & 2.17 & 3 \\
57 & 18.32 & - & 1 & 3 & 2 & - & 3 & 2.33 & 3 \\
58 & 146.18 & 3 & 1 & 2 & 3 & 1 & 3 & 1.83 & 2 \\
59 & 107.98 & 3 & 2 & 3 & 2 & 1 & 3 & 2.50 & 4 \\
60 & 38.55 & 1 & 2 & 2 & 3 & 1 & 2 & 3.00 & 4 \\
61 & 24.70 & 3 & 2 & 3 & 2 & 2 & 3 & 2.20 & 3 \\
62 & 24.43 & 3 & 3 & 3 & 3 & - & 3 & 2.80 & 4 \\
63 & 12.32 & 3 & 2 & 3 & 2 & - & 1 & 2.60 & 4 \\
64 & 18.38 & 3 & 3 & 3 & 2 & - & 3 & 2.50 & 4 \\
65 & 7.28 & 3 & 1 & 3 & 3 & - & 3 & 2.67 & 4 \\
66 & 118.71 & 3 & 1 & 3 & 2 & 3 & 3 & 2.40 & 3 \\
67 & 152.17 & 3 & 2 & 3 & 2 & 3 & 3 & 2.83 & 4 \\
68 & 53.01 & 2 & 2 & 3 & 2 & - & 3 & 1.40 & 1 \\
69 & 11.70 & 3 & 3 & 3 & 3 & 3 & 2 & 2.50 & 4 \\
70 & 28.94 & 1 & 1 & 1 & 2 & - & 2 & 2.60 & 4 \\
71 & 24.79 & 3 & 3 & 2 & - & - & 2 & 2.25 & 3 \\
72 & 98.37 & 3 & 2 & 3 & 2 & - & 3 & 2.80 & 4 \\
73 & 14.85 & 3 & 1 & 2 & - & - & 3 & 2.67 & 4 \\
74 & 20.40 & 3 & 2 & 3 & 3 & - & 3 & 2.80 & 4 \\
75 & 22.75 & 3 & 2 & 3 & 3 & 3 & 2 & 2.60 & 4 \\
76 & 12.66 & 3 & 2 & 3 & 3 & - & 3 & 2.50 & 4 \\
77 & 81.52 & 3 & 2 & 3 & 2 & - & 3 & 2.60 & 4 \\
78 & 58.74 & 3 & 1 & 3 & - & - & 3 & 2.60 & 4 \\
79 & 12.90 & 3 & 2 & 2 & 3 & - & 3 & 3.00 & 4 \\
80 & 16.45 & 3 & 1 & 3 & 3 & - & 3 & 2.50 & 4 \\
81 & 111.95 & 3 & 3 & 3 & - & - & 3 & 2.80 & 4 \\
82 & 49.20 & 3 & 1 & 3 & 3 & 3 & 2 & 2.83 & 4 \\
83 & 1048.63 & 3 & 3 & - & 2 & 3 & 3 & 2.50 & 4 \\
84 & 74.01 & 3 & 3 & 3 & 2 & - & 3 & 2.75 & 4 \\
85 & 160.89 & 3 & 2 & 3 & 3 & 3 & 3 & 2.00 & 3 \\
86 & 42.34 & 3 & 1 & 3 & - & - & 3 & 3.00 & 4 \\
87 & 53.25 & 3 & 3 & 3 & - & - & 2 & 2.80 & 4 \\
88 & 177.04 & 1 & 2 & 3 & 2 & 2 & 2 & 2.50 & 4 \\
89 & 167.97 & 3 & 3 & 3 & - & - & 3 & 2.20 & 3 \\
\hline & & & & & & & & &
\end{tabular}

Table 3. The area and occupation percentage of each class of geomorphic index.

\begin{tabular}{|c|c|c|c|c|c|c|c|c|}
\hline \multicolumn{2}{|c|}{ Class 3} & \multicolumn{2}{|c|}{ Class 2} & \multicolumn{2}{|c|}{ Class 1} & \multicolumn{2}{|c|}{ No value } & \multirow{2}{*}{$\begin{array}{l}\text { Geomorphic } \\
\text { indices }\end{array}$} \\
\hline $\begin{array}{l}\text { Occupation } \\
\text { percentage }\end{array}$ & Area & $\begin{array}{l}\text { Occupation } \\
\text { percentage }\end{array}$ & Area & $\begin{array}{l}\text { Occupation } \\
\text { percentage }\end{array}$ & Area & $\begin{array}{l}\text { Occupation } \\
\text { percentage }\end{array}$ & Area & \\
\hline 36.2 & 1981.05 & 3.8 & 216.73 & 13.96 & 777.88 & 45.78 & 2495.17 & $V_{\mathrm{f}}$ \\
\hline 17.86 & 995.22 & 63.01 & 3454.9 & - & - & 19.32 & 1020.72 & $S_{\mathrm{m}, \mathrm{f}}$ \\
\hline 70.69 & 3938.40 & 4.8 & 264.92 & 3.92 & 218.89 & 19.96 & 1048.62 & $B_{\mathrm{S}}$ \\
\hline 38.47 & 2143.36 & 31.6 & 1730.88 & 28.65 & 1596.60 & - & - & $A_{\mathrm{f}}$ \\
\hline 87.83 & 4893.04 & 1.70 & 72.54 & 8.57 & 477.93 & 0.69 & 27.32 & $S_{\mathrm{L}}$ \\
\hline 85.66 & 4761.16 & 10.87 & 561.95 & 2.65 & 147.73 & - & - & $H_{\mathrm{i}}$ \\
\hline
\end{tabular}


index, which have the same direction as Biseton limestone, are also seen in the area.

The south-western border Kermanshah radiolarite is bounded to the Koh-e Sefid fault (Fig. 13). This fault has thrusted Kermanshah radiolarites onto Amiran flysches.

The thickness of fault breccias in this place reaches up to $100 \mathrm{~m}$. The mentioned breccias are made of radiolarite, limestone, and sandstone elements. The activity of the Koh-e Sefid and Sarab faults can be a reason for the increase in relative tectonic activity at the end of the study area. The Koh-e Sefid anticline (Fig. 7) is located between the Gharasu and Mereg rivers. Although the Mereg source is located $15 \mathrm{~km}$ south of the Gharasu River, to reach the Gharasu, this river needs to travel almost $140 \mathrm{~km}$ towards the north-west to join the Gharasu in the Doab region.

\section{Conclusions}

It seems that the calculated geomorphic indices by using GIS are suitable for assessment of the tectonic activity of the study area. The geomorphic indices such as streamgradient index $\left(S_{\mathrm{L}}\right)$, drainage basin asymmetry $\left(A_{\mathrm{f}}\right)$, hypsometric integral $\left(H_{\mathrm{i}}\right)$, valley floor width-valley height ratio $\left(V_{\mathrm{f}}\right)$, drainage basin shape $\left(B_{\mathrm{s}}\right)$, and mountain-front sinuosity $(J)$, are calculated in the Gharasu basin. Therefore, firstly, the area was divided into 89 sub-basins and, for each one, indices were calculated; then, all of the indices were divided into three classes. Afterwards, six measured indices for each sub-basin were compounded and a unit index obtained as the relative tectonic activity $\left(I_{\text {at }}\right)$. This index was divided into four classes of tectonic activities: very high, high, moderate, and low. The area and occupation percentage for each class of index were calculated. As can be seen (in Table 3), most of the high percentages in the area are located in class 3 , which shows low tectonic activity.

The total area is composed of class $1\left(I_{\mathrm{at}}\right)$ with an area of about $28.94 \mathrm{~km}^{2}(0.53 \%)$, class $2\left(I_{\mathrm{at}}\right)$ with an area of about $173.96 \mathrm{~km}^{2}(3.18 \%)$, class $3\left(I_{\mathrm{at}}\right)$ with an area of about $1162.97 \mathrm{~km}^{2}(21.26 \%)$, and class $4\left(I_{\mathrm{at}}\right)$ with an area of about $4104.98 \mathrm{~km}^{2}(75.03 \%)$. Class 1 is located around the Dokeral anticline, class 2 is located to the north-eastern flank of the Nesar and Naraman mountains, class 3 is scattered to the western border of the study area, and a part of it has the same trending, with Bisotun limestone in the middle part of the study area.

The other parts of the area have class 4 of $I_{\text {at }}$. Sub-basin 68 is a single sub-basin with a very high value of $I_{\text {at }}$ located on the Dokeral anticline in the crush zone in Zagros.

Most of the areas with high and moderate values of latitude are located in the crush zone in the Zagros region too. Crushing of this zone is due to the main fault mechanism of the Zagros region. Seeing that these faults have a NE-SW direction, the areas with high and moderate values tend to develop in this direction. The results of this paper confirm previous research in this region. At the end of the eastern part of the study area, the value of $I_{\text {at }}$ is high, which could be the result of the Sarab and Koh-e Sefid fault mechanisms.

Acknowledgement. This work is funded by the department of geology, Islamic Azad University, Science and Research branch, Tehran, Iran. Also, Special thanks to Prof. A. Jordán to refine our article and vice-President for Research in the Science and Research branch, Tehran.

Edited by: A. Jordán

\section{References}

Arian, M. and Hashemi, S. A.: Seismotectonic Zoning in the Zagros, J. Sci., 18, 63-74, 2008.

Braud, J.: Geological map of Kermanshah area, scale $1: 250000$ Geologic Survey of Iran, 1979.

Bull, W. B.: Tectonic geomorphology of mountains: a new approach to paleoseismology, Blackwell, Malden, 2007.

Bull, W. B. and McFadden, L. D.: Tectonic geomorphology north and south of the Garlock fault, California, in: Geomorphology in Arid Regions, edited by: Doehring, D. O., Proceedings of the Eighth Annual Geomorphology Symposium, State University of New York, Binghamton, 115-138, 1977.

Cannon, P. J.: Generation of explicit parameters for a quantitative geomorphic study of Mill Creek drainage basin, Oklahoma Geology Notes, 1, 3-16, 1976.

Dehbozorgi, M., Pourkermani, M., Arian, M., Matkan, A. A., Motamedi, H., and Hosseiniasl, A.: Quantitative analysis of relative tectonic activity in the Sarvestan area, central Zagros , Iran. Geomorphol., 121, 329-341, 2010.

El Hamdouni, R., Irigaray, C., Fernandez, T., Chacon, J., and Keller, E. A.: Assessment of relative active tectonics, southwest border of Sierra Nevada (southern Spain), Geomorphology, 96, 150173, 2008.

Hack, J. T.: Studies of longitudinal stream-profiles in Virginia and Maryland, US Geol. Surv. Profess. Paper, 294B, 45-97, 1957.

Hack J. T.: Stream-profiles analysis and stream-gradient index, J. Res. USA, Geol. Surv., 1, 421-429, 1973.

Hack, J. T.: Physiographic division and differential uplift in the piedmont and Blue Ridge, US Geol. Surv. Profess. Paper, 1265, $1-49,1982$.

Hare, P. W. and Gardner, T. W.: Geomorphic indicators of vertical neotectonism along converging plate margins, Nicoya Peninsula, Costa Rica, in: Tectonic Geomorphology, edited by: Morisawa, M. and Hack, J. T., Proceedings of the 15th Annual Binghamton Geomorphology Symposium, Allen and Unwin, Boston, 123134, 1985.

Karimi, A. R.: Geological map of Kermanshah area, scale 1: 100000 , Geologic Survey of Iran, 1999.

Keller, E. A.: Investigation of active tectonics: use of surficial Earth processes, in: Active tectonics, edited by: Wallace, R. E., Studies in Geophysics, National Academy press, Washington DC, 136147, 1986.

Keller, E. A. and Pinter, N.: Active tectonics: Earthquakes, Uplift, and Landscape (2nd Edn.), Prentice Hall, New Jersey, 432, 2002. 
Memarian, H.: Geology for engineers, Tehran University Press, 2001 (in Persian).

Mirzaei, N., Gao, M., and Chen, Y. T.: seismic source regionalization for seismic zoning of Iran: Major seismotectonic provinces, J. Earth. Predict. Res., 7, 465-495, 1998.

Molin, P., Pazzaglia, F. J., and Dramis, F.: Geomorphic expression of active tectonics in a rapidly-deforming forearc, sila massif, Calabria, southern Italy, Am. J. Sci., 304, 559-589, 2004.

Nazari, H.: Geological map of Harsin area scale 1 : 100 000, Geologic Survey of Iran, 1998.

Ramirez-Herrera, M. T.: Geomorphic assessment of active tectonics in the Acambay Graben, Mexican volcanic belt, Earth Surf. Proc. Land., 23, 317-332, 1998.

Rockwell, T. K., Keller, E. A., and Jonson, D. L.: Tectonic geomorphology of alluvial fans and mountain fronts near Ventura, California, in: Tectonic Geomorphology, edited by: Morisawa, M., Proceedings of the 15th Annual Geomorphology Symposium, Allen and Unwin Publishers, Boston, 183-207, 1985.
Sadeghian, M. and Delavar, S. T.: Geological map of Kamyaran area scale $1: 100000$, Geologic Survey of Iran, 2007.

Silva, P. G.: Evolutiongeodinamica de la depression del Guadalentindesde el Miocene superior hasta la Actualidad: Neotectonic age omorfologia, Ph.D. Dissertation, Complutense University, Madrid, 1994.

Silva, P. G., Goy, J. L., Zazo, C., and Bardajm, T.: Fault generated mountain fronts in Southeast Spain: geomorphologic assessment of tectonic and earthquake activity, Geomorphology, 250, 203226, 2003.

Strahler, A. N.: Hypsometric (area-altitude) analysis of erosional topography, Geol. Soc. Am. Bull., 63, 1117-1142, 1952.

Wells, S. G., Bullard, T. F., Menges, T. M., Drake, P. G., Karas, P. A., Kelson, K. I., Ritter, J. B., and Wesling, J. R.: Regional variations in tectonic geomorphology along segmented convergent plate boundary, Pacific coast of Costa Rica, Geomorphology, 1, 239-265, 1988. 